\title{
Firewood knowledge, use and selection by rural populations in the Dry Chaco of Sierra de Ancasti, Catamarca, Argentina
}

\author{
N. David Jiménez-Escobar ${ }^{1 *}$ and Gustavo J. Martínez ${ }^{1}$
}

\begin{abstract}
Firewood extraction and consumption are practices that require specific knowledge as well as detailed analysis of the cultural context in which they take place. The appropriation, use and selection of wood fuel resources were determined through open and semi-structured interviews, guided walks, participant observation and re-call. Currently, the rural inhabitants of the Sierra de Ancasti, Catamarca (Dry Chaco's forest) know about, manage, use, and appropriate firewood resources to meet their needs related to heating and preparing food in their homes. We identified 52 species (corresponding to 44 genera, 23 families) associated with the domestic use of fire. Among these, 42 species $(81 \%)$ are currently used for food preparation, 23 species (44\%) in heating and 16 species (31\%) in fire ignition and production. Based on an analysis of frequency of mention and the Cognitive Salience Index, the most important and preferred species among the inhabitants are Condalia spp., Lithraea molleoides and Vachellia caven. Factors that determine the selection of the species include firewood quality, accessibility and distance. Additional factors such as the high richness of firewood species used and known in the region, the flexibility of the inhabitants in their choice of species, the exclusive use of firewood for domestic purposes, collection of dead wood, and the use of several adventitious-cultivated species associated with domestic spaces, could be reducing the pressure on the native species and on the Dry Chaco forest in general.
\end{abstract}

Keywords: Dry Chaco; Ethnobotany; Fuelwood; Rural Communities; Sierra de Ancasti.

\footnotetext{
${ }^{1}$ IDACOR-CONICET, Museo de Antropología, Facultad de Filosofía y Humanidades. Universidad Nacional de Córdoba, Hipólito Yrigoyen 174 - X5000JJC- Córdoba, Argentina.
}

* Corresponding author. $\square$ E-mail address: ndjimeneze@gmail.com

\section{INTRODUCTION}

Firewood or fuelwood species are defined as those plants used for combustion, a process through which heat is produced and thus, energy is released. It is mainly used for room heating and food cooking, including water heating (Albuquerque et al. 2010). The use of fuelwood resources is the one of main energy sources of rural populations in various ecosystems worldwide (Fox 1984; Valderrama and Linares 2008; Martínez 2015). It is favored over other alternatives because it is relatively accessible, 
affordable, and easy to use, among other socio-economic, cultural, climatic and regional reasons (e.g. availability or abundance) (Abbot et al. 1997; Ghilardi et al. 2007; Ramos et al. 2008).

Fuelwood gathering for fire production is a topic of paramount importance worldwide (FAO 1983, 2008). Population growth, increasing poverty and expansion of agricultural borders are some of the main factors leading to the shortage and lack of firewood supplies (Kataki and Konwer 2002; San et al. 2012). In places where there is not enough vegetation to meet inhabitants' needs, and the demand is higher than the replacement rate, pressure is put on natural resources, which has a negative impact on environmental balance (Chettri et al. 2002; Tabuti et al. 2003; Ramos et al. 2008). Not only do these negative impacts (including deforestation and loss of natural habitats) affect ecosystems, but they also put the inhabitants' economic and social well-being at risk. Therefore, detailed studies on the selection, extraction and consumption of firewood should consider both the environmental and socioeconomic contexts in which these activities take place (Cardoso et al. 2013; Martínez 2015).

In the specific case of fuelwood resources, some characteristics such as abundance, quality, access, and availability may have a significant influence on the local perception of nearby forests and ecosystems (FAO 2008; Martínez 2015). However, the criteria that local inhabitants use when selecting species for extraction, or for preferring some species over others are still unclear, and generally far from being fully understood in scientific terms (Chettri and Sharma 2009). Some studies suggest that the domestic use of firewood is related to wood quality, in which preference is shown for species with desirable intrinsic properties (rapid growth, easy cutting, quick drying, low weight and good combustion characteristics), resorting to other species only in the absence of preferred species (Abbot et al.1997; Kituyi et al. 2001; Ramos et al. 2008). Conversely, other studies show that inhabitants use all the firewood species associated with a collection area (San et al. 2012), which, in turn, could explain the wide variety of species used. Ramos and Albuquerque (2012) established that use and local abundance are related to seasonality. Nonetheless, only a few studies, including that of Ramos et al. (2008), focused on the differences between firewood species and how these are related to preference and selection.

In rural and peri-urban populations of Argentina, firewood is one of the main sources of fuel for heating indoor spaces and cooking food (Arre et al. 2015). Several studies related to the management and diversity of this resource in the Patagonian steppe have been published recently (Cardoso and Ladio 2011; Cardoso et al. 2012, 2013, 2015, 2017; Arre et al. 2015; Morales et al. 2017). The link between firewood use and cultural practices has also been documented in rural communities of Córdoba province (Martínez 2015; Rodríguez et al. 2015; Fernández 2017), and relevant contributions to the study of resource use in the Ambato Valley (Dry Chaco) area were made by Gadban (1999) and Marconetto (2008).

From an ethnobotanical perspective, the aim of this study is to gain insights into how important firewood is for the rural inhabitants of Sierra de Ancasti, and to answer the following questions: What species of firewood are known in the area? What are they used for? Where are they obtained? What criteria are followed to gather and use them? Which are the most important for the 
inhabitants? To answer these questions, two hypotheses are discussed: 1) Whether there is any relation between preferred firewood species and those that are actually used; 2) Whether the perceived quality of the wood (defined using local categories) is a determining factor in the selection of firewood species.

\section{MATERIAL AND METHODS}

\section{Study area}

Sierra de Ancasti is a town located in the Ancasti District, Catamarca Province, Argentina. Its urban center lies between 280 23'29.3" S, and 650 20'65.40" W (Figure 1). This mountain range, which is part of the Chaco phytogeographic region (Dry Chaco), is a system of Pampean Sierras (Pampean mountains) measuring over $1,200 \mathrm{~m}$ in altitude. Several ecoregions converge there, including the Yungas (Transition Forest, Montane Forest), the Monte de Sierras and Bolsones, and the region stretching from Chaco Seco to Chaco Serrano (Morláns 1995; Perea et al. 2007; Palmeri et al. 2008; Maldonado 2011). The region is characterized by a warm-humid climate with an average annual temperature of $190 \mathrm{C}$ and average annual rainfall ranging from 500 to $1,200 \mathrm{~mm}$ per year, mostly occurring during the summer season (Bazán 2006; Palmeri et al. 2008).

Characterized by mountainous relief, the region features high meadows with natural pastures, streams and small intermontane valleys and mountainsides with woody formations. The vegetation in the area is a mixture of arboreal elements typical of the semi-arid Chaco, such as Geoffroea decorticans (Gillies ex Hook. \& Arn) Burkart., Jodina rhombifolia (Hook. \& Arn.), Reissek and Schinopsis lorentzii (Griseb.) Engl, with

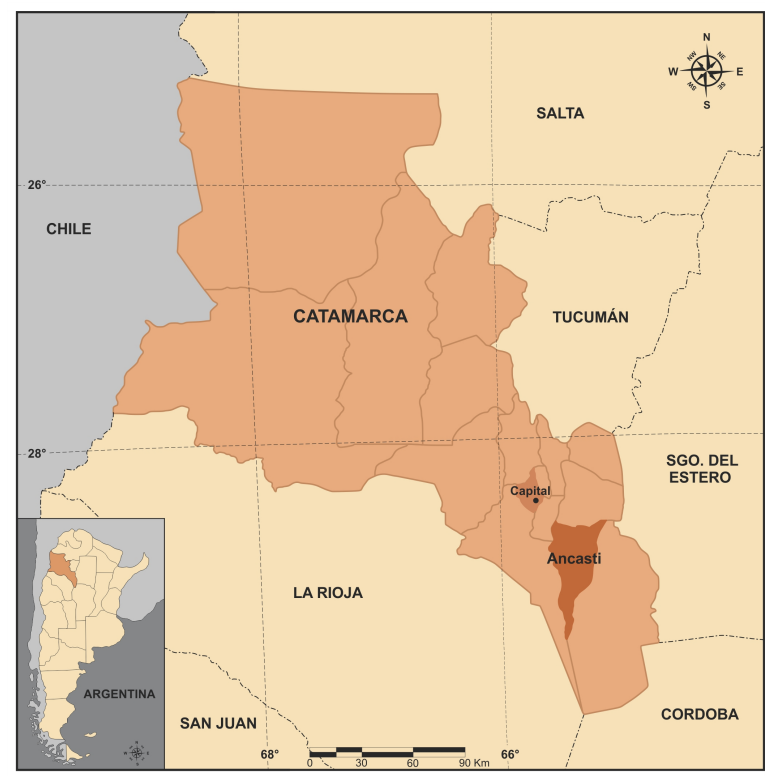

Figure 1. Study area, Ancasti district, Catamarca Province, Argentina.

elements typical of the montane Chaco, such as Parasenegalia visco (Lorentz ex Griseb.) Seigler \& Ebinger, Ruprechtia apetala (Wedd.) and Zanthoxylum coco (Gillies ex Hook. F. \& Arn.) and species from the Yungas eco-region -transition forest or Cebil forest- such as Anadenanthera colubrina (Vell.) Brenan, Erythroxylum argentinum (O.E. Schulz) and Xylosma pubescens (Griseb.). Tall meadows or misty pastures are one of the most representative landscapes of the Sierra at 1000-1200 m altitude. This region is characterized by strongly marked climatic seasonality with a broad range of native grasslands (Elionurus muticus (Spreng.) Kuntze, Festuca hieronymi Hack., Jarava ichu Ruiz \& Pav., Poa calchaquiensis Hack., Setaria macrostachya Kunth, among others), with some herbaceous to shrubby elements (Baccharis flabellata Hook. \& Arn., Berberis ruscifolia Lam., Croton lachnostachyus Baill., and Ephedra tweediana Fisch. \& CA Mey.). The vegetation in the environments of eastern Catamarca has been documented in phytogeographic studies (Morláns 1995), 
floras (Perea et al. 2007; Quiroga and Reinoso-Franchino 2010; Perea 2011,) and forage grasses in the Dry Chaco (Quiroga and Correa 2011). Recent ethnobotanical contributions in the region include the relationships between criollos of Ancasti and forage bromeliads (Jiménez-Escobar 2015), and between criollos and plants of veterinary interest (Martínez and Jiménez-Escobar 2017).

\section{Sierra inhabitants}

According to the most recent data from the National Institute of Statistics and Census (INDEC 2010), the Sierra district has a population of 2,900 inhabitants in a total of 786 households. This most recent national census provides relevant information about the use of firewood and coal, since it is estimated that about $45 \%$ of Ancasteños (people from Ancasti) depend on this resource for cooking. Furthermore, the coverage of electrical power in the district is about $90 \%$, and every town has access to drinking water (Bazán 2006). In terms of public health, in Ancasti, there are 22 health posts, and there is one hospital in the urban center.

The rural inhabitants of the region define themselves as criollos-serranos (Mountain locals) and lead a peasant lifestyle. Their subsistence economy is mainly associated with traditional systems-the open field system-of livestock production (bovine, goat and sheep). Family farming is oriented towards self-sufficiency, generally including small farms, where corn (Zea mays L.) and squash (Cucurbita maxima Duch) are the main crops. According to INDEC (2010), over the last few decades, the population has been in a continual decline due to the migration of Catamarca's rural inhabitants to urban centers. Lack of employment, changing land-use patterns, and lack of technological-professional educational centers are some of the main reasons why they leave their land.

\section{Fieldwork phase}

For this project, six field trips to the rural community of the Sierra de Ancasti were made between August 2014 and July 2017. Additionally, this research draws on information collected by the Ethnobiology team of IDACOR-Anthropology Museum of the National University of Cordoba (UNC), whose members have been making multiple field trips to the area since 2011. This study was conducted in accordance with the standard epistemological and methodological considerations of ethnobotanical research (Alexiades 1996; Martin 2001; ISE 2006; Albuquerque et al. 2010; Anderson et al. 2011).

Prior to the interviews with the inhabitants, the municipal representatives and the State Office for Environment and Development in the province were informed about the research project and its objectives. Likewise, each household was introduced to the project, and collaboration was requested through verbal consent, in accordance with the Code of Ethics of the International Society of Ethnobiology (ISE 2006). The household was the basis of our analyses, where interviews and personal talks and walks with all its members (regardless of gender, age, role in the home) were conducted. A total of 87 inhabitants of the area, belonging to 46 households, participated in open interviews with questions focused on determining the cultural importance of the species. The inhabitants were also asked about their perceptions of, the common names for, and the local categories of use related to these 
species (Karremans 1994; Albuquerque et al. 2010).

After reaching 46 households using the availability criterion and the snowball sampling technique, 31 families agreed to participate in a semi-structured survey about firewood, through which they were consulted about: richness of species used at home, important species and preference criteria, uses (heating, cooking, etc.), gathering or acquisition, yearly gathering cycle, storage, and specifications to produce fire and maintain it. The recall method (Re-call) was also used, including, in the interviews, the question: When was the last time you used firewood and which type(s) of firewood did you use? (Alexiades et al. 1996; Höft et al. 1999). At the same time and in a complementary way, ethnographic records were kept, occasional dialogues were established, and data were collected with the participant observation technique (Guber 2004; Albuquerque et al. 2010).

Guided walks and botanical collections of firewood species were conducted with the presence of knowledgeable criollos (men or women from 10 households, visiting the collection areas, one or several times, when they were looking for firewood outside). Botanical specimens were collected and preserved according to established standards (Mori et al. 2011). For their taxonomic classification, we resorted to specialized literature (Vascular Flora of the Southern Cone, Vascular Flora of the Argentine Republic) and local flora information (Perea et al. 2007; Perea 2011). Taxonomic specialists were also consulted, and species identities were corroborated in the herbarium. Subsequently, the entire collection was deposited in the herbarium closest to the region, the Herbarium of the Botanical Museum (CORD), Multidisciplinary Institute of Plant Biology (IMBIV), at the
National University of Córdoba, Argentina, under the N.D. Jiménez-Escobar and G.J. Martínez numbering series.

\section{Data analysis}

The frequency of mention corresponds to the number of inhabitants who mentioned the species divided by the total of the interviewees (31). In order to make the comparisons, the categories of use follow the considerations proposed by other researchers on firewood species in Argentina (Martínez 2015, Fernández 2017), which coincide with local categories. During the interviews, people were asked What was the last firewood species that you used? Based on the results and the frequencies of the responses, the recall method was applied. To establish preferences and define which species are considered the most important, two questions were posed at the end of each interview: Of all the firewood species that you have just mentioned, which ones do you like the most? and Why did you choose those three species? With the answers, Cognitive Salience Index (CSI) was assessed, calculated according to the frequency and ranking of the answers (Sutrop 2001). Firewood quality, abundance, and availability were not measured in this study. These variables were determined directly by the criollos and defined in local terms.

\section{RESULTS AND DISCUSSION}

\section{General aspects of firewood collection}

Firewood is collected close to the owner's home (within a $1 \mathrm{~km}$ walk), by hand, with a machete or axe (to a lesser extent, with a chainsaw). The general pattern, 
corroborated through participant observation, consists of collection of trunks, sticks and dry or fallen branches, which are carried home in the collector's arms (sometimes tied). In general, the boughs are thin -between 3 to $20 \mathrm{~cm}$ in diameter- and all together can weigh on average $10 \mathrm{~kg}$. Firewood collection is almost a daily practice, carried out by both men and women of any age. However, women are key in the administration and use of firewood, mainly for cooking and preparing food. Although no specific time for collection has been observed, it is usually done "early" in the morning or afternoon (before getting dark). According to criollos, going for firewood is an activity that increases at the end of April in the autumn season and remains constant during the winter (colder season in the year, where firewood is required to heat the houses). Collecting firewood may or may not be an exclusive activity. There are specific times for collecting firewood and times for working with the animals, cleaning the farm, preparing animal feed and, on the way home, it is common to pick up some dry firewood.

In general, there are embers on the stove all day long, although the intensity of the flame is managed according to the hours when cooking occurs. The fire is also related to the care of domestic animals - "we are gathering firewood all the time so as to have the stove always on and cook food for the animals (dogs), but we burn more firewood when having good roasted meat" (E.B. 65 years old). Participant observation was employed to study the materials used to light the stove fires. Neither dung, manure nor green wood were observed. Instead, plastic (food wrappers), cartons, and fruit boxes (industrialized wooden boxes generally used to transfer fruit to the produce shop) were added to the stove fire. However, this is more of a spontaneous than a planned practice. Likewise, waste from pruning or felling of all types of wood near the house, including fruit species, can serve as firewood. These observations are consistent with those of Cardoso et al. (2012) who show how the recycling of biological products to supplement firewood, together with forestry practices, can contribute to the resilience of the inhabitants of the arid environments of Patagonia.

Although some inhabitants have access to gas cylinders or tanks, they still use a stove and stove fire to cook. Some of the stories told by the locals revealed the reasons why firewood is still being used: "there are always some embers in the stove, to cook for animals... so, we don't spend so much on gas" (E.B., 70 years old) or "I use firewood to cook things that take time, to save gas" (M.V., 57 years old). This practice is associated with a gas saving factor, which in turn translates into economic savings. But this may not be the only reason. Other important factors accounting for the continued use of stove fires are directly related to time and taste: "And there is nothing better than a good roasted meat like this, with churqui (Vachelia caven; a native shrub)" (D.P. 64 years old) and "the truth is that, gradually, less wood is used ... except for a stew, a locro (traditional stew, the dish is a corn, beans and pumpkin soup) or something like that" (J.V. 63 years old).

Very few households buy firewood to supply their needs during the winter season (18\%), with Anadenanthera colubrina, and Schinopsis lorentzii as the two most commercialized species in the area. However, about $86 \%$ of the interviewees said that they do buy charcoal. Charcoal is sold in paper bags weighting from 3 to $4 \mathrm{~kg}$, and can be easily bought in the surrounding 
stores. Some of these bags read: "Quebracho firewood"; even so, the inhabitants claim that the origin of this product is unknown to them, although purchasing it is very common, and it is directly associated with the traditional asado (barbecued beef). Some criollos say that this tendency to acquire coal is recent. Win et al. (2018) state that, given the development and urbanization in rural populations, an increase in charcoal production and a transition fuelwood to charcoal are expected.

Among the rural inhabitants there is no generalized idea of scarcity of firewood, not even in winter, the time of greatest consumption. However, some older criollos say that, despite firewood being available, the highest quality species are running out: "Firewood is running out; we need to go as far as $6 \mathrm{~km}$ to get some good firewood" (H.F. 80 years old), which implies traveling greater distances.

In all the semi-structured interviews, the inhabitants stated that they used firewood at least once during the past year to cook food and heat their homes during the winter. Therefore, it can be confirmed that firewood is essential for the criollos in Sierra de Ancasti, both for cooking all year round (for example, asados, bread and desserts) and heating in the winter (braziers, water heaters, and wood burners). In addition, firewood species and fire production are actively involved in the construction of the social fabric of the criollos (when water for a mate -Argentine infusion of Ilex paraguariensis- is heated in a brazier and then shared, or when a cold room is heated in the winter). Finally, one of the statements that describes this activity in general terms is: "Here no wood goes unused. Every single tree that falls or dries is a tree that is used for firewood" (H.F., 80 years old). This shows the flexibility and plasticity of the local inhabitants when using different types of firewood (Figure 2).

\section{Ancasti firewood}

This study revealed that 52 species of plants belonging to 44 genera, and 23 botanical families are used as firewood (Table 1). The Fabaceae s.l. family had the highest number of species (13), followed by Salicaceae (5) and Rhamnanceae (4). In Sierra de Ancasti, a large number of native fuelwood species - wild plants - has been reported $(73 \%)$, compared to adventitious, cultivated, or naturalized species $(27 \%)$. In total, 71 common or vernacular names are registered for plant species associated with practices and use of fire. When ranked by habit, most of the firewood species are trees (38 spp; 73\%,) followed by shrubs or subshrubs (14 spp; $27 \%$ ).

When comparing fuelwood species richness with that from other rural areas of the Chaco Serrano Forest, the results obtained here are similar to the 56 species registered by Martínez (2015). However, the diversity in Ancasti is greater than that reported by Fernández (2017), who cites 37 species of firewood in the Colón district, Córdoba, with about 21 species common to both areas. In comparison with other geographical regions of Argentina, the richness of species used in Ancasti is considerably higher: about two and a half times more than in the Patagonian steppe (Cardoso et al. 2012, 2013,) and almost twice as much as in eastern Catamarca (Gadban 1999). Although in this study we did not evaluate the effects of the collection of firewood and its link with the rate of deforestation or extraction of native plants, one could begin to consider that this wide repertoire of species (51 sp.) reflects the flexibility of the criollos, who could be 

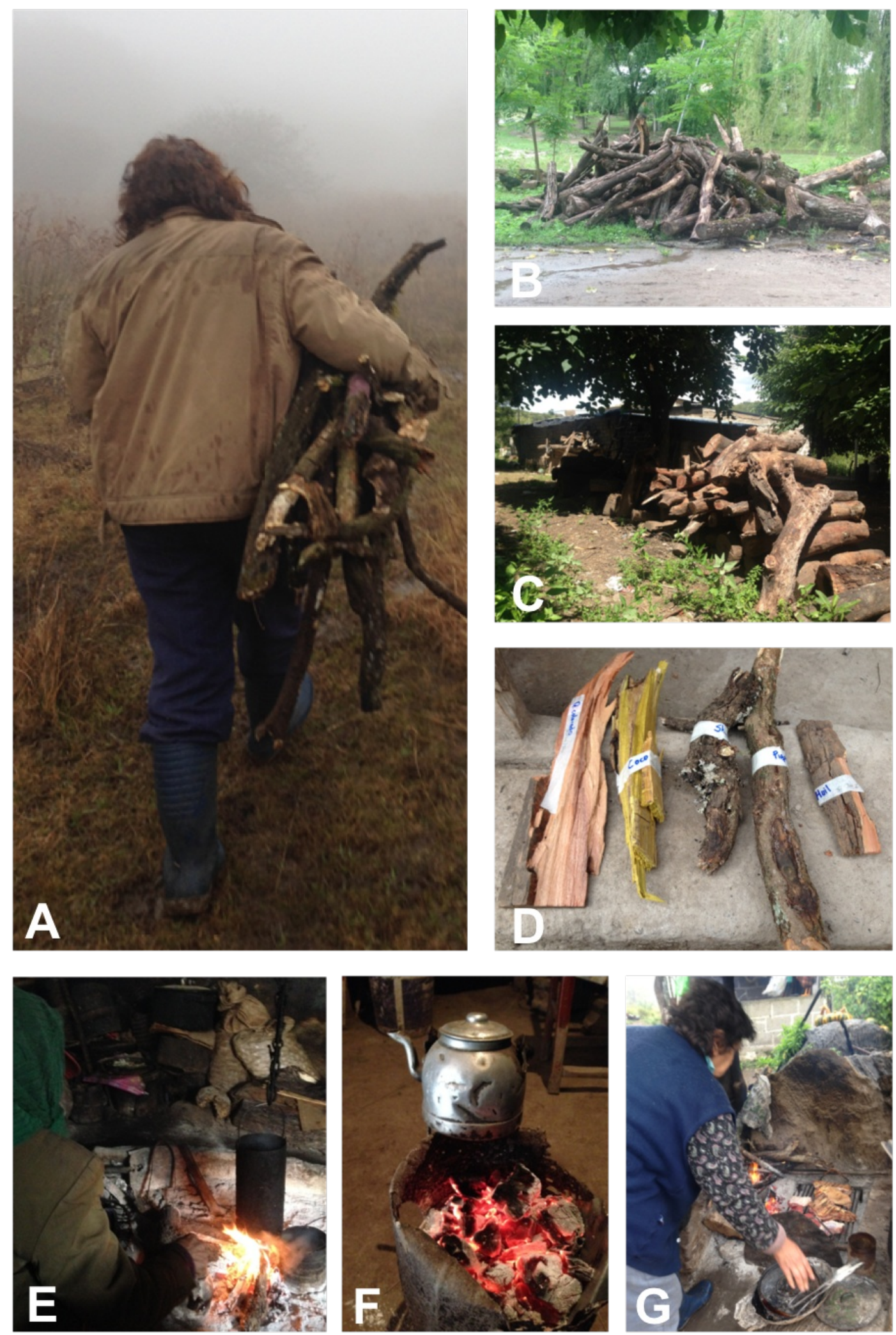

Figure 2. Firewood for the criollos of Sierra de Ancasti, Catamarca, Argentina. A: collection. B, C: stacks of firewood (B: Salix humboldtiana, C: Shinopsis lorentzii). D: diversity. E, F, G: applications and uses (food preparation). 
Table 1. Annotated list of the fuel plant species of Sierra de Ancasti, Catamarca, Argentina.

In alphabetical order by botanical family, scientific name and reference specimen deposited in CORD (voucher). Common names. Origin: native of Argentina (N), adventitious, cultivated or naturalized (A). Frequency of mention ( $\mathrm{Fr} \%)$. Uses: Cooking and food preparation (Co: cooking and boiling (c), oven (o), roast (r)); Heating (He: brazier (b), salamander stoves (s), water heater $(\mathrm{w})$ ); Kindling and production of flame (St: embers and coals $(\mathrm{e})$, kindling $(\mathrm{k})$ ). The $\left(^{*}\right)$ symbol, indicates that the species does not have a reference specimen.

\begin{tabular}{|c|c|c|c|c|}
\hline $\begin{array}{l}\text { FAMILY } \\
\text { Species (voucher CORD) }\end{array}$ & Common names & Origin & $\operatorname{Fr} \%(n: 31)$ & Uses \\
\hline \multicolumn{5}{|l|}{ ANACARDIACEAE } \\
\hline Lithraea molleoides (Vell.) Engl. (GJM 883) & $\begin{array}{l}\text { molle cordobés, molle de beber, } \\
\text { molle }\end{array}$ & $\mathrm{N}$ & 64.5 & $\mathrm{Co}(\mathrm{c}, \mathrm{o}, \mathrm{r}) ; \mathrm{He}(\mathrm{b}) ; \mathrm{St}(\mathrm{e})$ \\
\hline Schinopsis lorentzii (Griseb.) Engl. (GJM 950, 1300) & quebracho colorado & $\mathrm{N}$ & 58.1 & $\mathrm{Co}(r) ; \mathrm{He}(\mathrm{b}) ; \mathrm{St}(\mathrm{e})$ \\
\hline $\begin{array}{l}\text { Schinus fasciculatus (Griseb.) I.M. Johnst. var. } \\
\text { fasciculatus (GJM 1252, 1263; NDJ 2303) }\end{array}$ & $\begin{array}{l}\text { molle incienso, molle pispo, molle } \\
\text { sonso, molle tonto }\end{array}$ & $\mathrm{N}$ & 25.8 & $\mathrm{Co}(\mathrm{c}, \mathrm{r})$ \\
\hline \multicolumn{5}{|l|}{ APOCYNACEAE } \\
\hline Aspidosperma quebracho-blanco Schltdl. (GJM 1239) & quebracho blanco & $\mathrm{N}$ & 22.6 & Co(r); St(e). \\
\hline Vallesia glabra (Cav.) Link (GJM 932) & ancoche & $\mathrm{N}$ & 3.2 & St(k). \\
\hline \multicolumn{5}{|l|}{ ASTERACEAE } \\
\hline Baccharis flabellata Hook. \& Arn. (NDJ 2245) & clavillo & $\mathrm{N}$ & 6.5 & St(k). \\
\hline \multicolumn{5}{|l|}{ BERBERIDACEAE } \\
\hline Berberis ruscifolia Lam. (GJM 1313; NDJ 1985) & chilca & $\mathrm{N}$ & 3.2 & $\mathrm{Co}(\mathrm{c})$. \\
\hline \multicolumn{5}{|l|}{ BIGNONIACEAE } \\
\hline Tabebuia nodosa (Griseb.) Griseb. (GJM 1096) & palo cruz & $\mathrm{N}$ & 3.2 & $\mathrm{Co}(\mathrm{r})$. \\
\hline \multicolumn{5}{|l|}{ CELTIDACEAE } \\
\hline $\begin{array}{l}\text { Celtis ehrenbergiana (Klotzsch) Liebm. var. } \\
\text { ehrenbergiana (GJM 1091) }\end{array}$ & tala, tala pispo & $\mathrm{N}$ & 3.2 & $\mathrm{Co}(\mathrm{r})$ \\
\hline Celtis iguanaea (Jacq.) Sarg. (GJM 1055; NDJ 2249) & horco tala, tala & $\mathrm{N}$ & 64.5 & $\mathrm{Co}(\mathrm{c}, \mathrm{o}, \mathrm{r}) ; \mathrm{He}(\mathrm{b}, \mathrm{s}, \mathrm{w}) ; \mathrm{St}(\mathrm{s}, \mathrm{e})$. \\
\hline \multicolumn{5}{|l|}{ CERVANTESIACEAE } \\
\hline Jodina rhombifolia (Hook. \& Arn.) Reissek (GJM 914) & sombra de toro & $\mathrm{N}$ & 9.7 & $\mathrm{Co}(r)$. \\
\hline \multicolumn{5}{|l|}{ ERYTHROXYLACEAE } \\
\hline $\begin{array}{l}\text { Erythroxylum argentinum O.E. Schulz (GJM 1058, } \\
\text { 1156) }\end{array}$ & $\begin{array}{l}\text { ají de paloma, aji de zorro, avilla, } \\
\text { cantospie, rajadilla, rajilla }\end{array}$ & $\mathrm{N}$ & 9.7 & $\mathrm{He}(\mathrm{b}) ; \mathrm{St}(\mathrm{k})$ \\
\hline \multicolumn{5}{|l|}{ FABACEAE } \\
\hline $\begin{array}{l}\text { Anadenanthera colubrina (Vell.) Brenan var. cebil } \\
\text { (Griseb.) Altschul (GJM 925) }\end{array}$ & cebil & $\mathrm{N}$ & 48.4 & $\mathrm{Co}(\mathrm{r}) ; \mathrm{He}(w)$ \\
\hline $\begin{array}{l}\text { Geoffroea decorticans (Gillies ex Hook. \& Arn.) } \\
\text { Burkart (NDJ 2219) }\end{array}$ & chañar & $\mathrm{N}$ & 22.6 & $\mathrm{Co}(\mathrm{r}) ; \mathrm{St}(\mathrm{e})$ \\
\hline Mimosa farinosa Griseb. (GJM 889, 1087; NDJ 2023) & shinqui & $\mathrm{N}$ & 35.5 & $\mathrm{Co}(\mathrm{c}, \mathrm{o}) ; \mathrm{He}(\mathrm{w})$. \\
\hline $\begin{array}{l}\text { Mimozyganthus carinatus (Griseb.) Burkart (GJM } \\
\text { 1230) }\end{array}$ & lata & $N$ & 12.9 & $\mathrm{He}(\mathrm{b})$ \\
\hline $\begin{array}{l}\text { Parasenegalia visco (Lorentz ex Griseb.) Seigler \& } \\
\text { Ebinger (GJM 897, 1053, NDJ 2277) }\end{array}$ & viscote, viscote negro & $\mathrm{N}$ & 54.8 & $\mathrm{Co}(\mathrm{c}, \mathrm{r}) ; \mathrm{He}(\mathrm{b}, \mathrm{s}) ; \mathrm{St}(\mathrm{k})$ \\
\hline $\begin{array}{l}\text { Parapiptadenia excelsa (Griseb.) Burkart (GJM 1057, } \\
\text { 1256, 1324) }\end{array}$ & viscote colorado & $\mathrm{N}$ & 38.7 & $\mathrm{Co}(\mathrm{c}, \mathrm{r}) ; \mathrm{He}(\mathrm{b})$ \\
\hline Prosopis alba Griseb. (GJM 1223) & algarrobo & $\mathrm{N}$ & 58.1 & $\mathrm{Co}(o, r) ; \mathrm{He}(b) ; \mathrm{St}(\mathrm{e})$. \\
\hline Robinia pseudoacacia L. (NDJ 2361, 2386) & acacio & A & 9.7 & $\mathrm{Co}(\mathrm{w})$ \\
\hline Senna cf. aphylla (Cav.) H.S. Irwin \& Barneby $\left(^{*}\right)$ & retama & $\mathrm{N}$ & 3.2 & St(k). \\
\hline $\begin{array}{l}\text { Senegalia gilliesii (Steud.) Seigler \& Ebinger (GJM } \\
\text { 1235) }\end{array}$ & garabato & $\mathrm{N}$ & 3.2 & $\mathrm{Co}(\mathrm{c})$ \\
\hline $\begin{array}{l}\text { Senegalia praecox (Griseb.) Seigler \& Ebinger (GJM } \\
\text { 1086) }\end{array}$ & garabato negro & $\mathrm{N}$ & 9.7 & $\mathrm{Co}(\mathrm{r}) ; \mathrm{He}(\mathrm{b}, \mathrm{w})$ \\
\hline $\begin{array}{l}\text { Vachelia aroma (Gillies ex Hook. \& Arn.) Seigler \& } \\
\text { Ebinger (GJM 870, 1298; NDJ 2012) }\end{array}$ & algarrobilla, tusca, tusquilla & $\mathrm{N}$ & 32.3 & $\mathrm{Co}(\mathrm{o}, \mathrm{r}) ; \mathrm{He}(\mathrm{b})$ \\
\hline $\begin{array}{l}\text { Vachelia caven (Molina) Seigler \& Ebinger (GJM 871, } \\
\text { 1297) }\end{array}$ & churqui, tusca & $\mathrm{N}$ & 80.6 & $\mathrm{He}(\mathrm{b}, \mathrm{w}) ; \mathrm{Co}(\mathrm{c}, \mathrm{o}, \mathrm{r}) ; \mathrm{St}(\mathrm{e})$ \\
\hline \multicolumn{5}{|l|}{ JUGLANTACEAE } \\
\hline Juglans australis Griseb. (GJM 1046, NDJ 2020) & nogal, nogal cimarrón & $\mathrm{N}$ & 9.7 & $\mathrm{Co}(\mathrm{c}) ; \mathrm{He}(\mathrm{w})$. \\
\hline \multicolumn{5}{|l|}{ MALVACEAE } \\
\hline Ceiba chodatii (GJM 1031, NDJ 2296) & palo borracho & $\mathrm{N}$ & 3.2 & $\mathrm{Co}(\mathrm{c})$. \\
\hline \multicolumn{5}{|l|}{ MELIACEAE } \\
\hline Melia azedarach L. $\left(^{*}\right)$ & paraíso & A & 19.4 & $\mathrm{Co}(\mathrm{c}, \mathrm{o}) ; \mathrm{He}(\mathrm{w}) ; \mathrm{St}(\mathrm{k})$. \\
\hline \multicolumn{5}{|l|}{ MORACEAE } \\
\hline $\begin{array}{l}\text { Broussonetia papyrifera (L.) L'Hér. ex Vent. (GJM } \\
\text { 1243; NDJ 2287) }\end{array}$ & gomero, mora turca & A & 35.5 & $\mathrm{Co}(\mathrm{c}, \mathrm{o}, \mathrm{r}) ; \mathrm{He}(\mathrm{w})$ \\
\hline Ficus carica L. (GJM 1100; NDJ 2231, 2294) & higuera & A & 16.1 & $\operatorname{Co}(r)$ \\
\hline Morus alba L. $\left({ }^{*}\right)$ & mora criolla & A & 48.4 & $\mathrm{Co}(\mathrm{c}, \mathrm{o}, \mathrm{r}) ; \mathrm{He}(\mathrm{w})$ \\
\hline \multicolumn{5}{|l|}{ MYRTACEAE } \\
\hline Eucalipthus spp. & eucalipto & A & 3.2 & $\mathrm{Co}(0)$ \\
\hline $\begin{array}{l}\text { Myrcianthes cisplatensis (Cambess.) O. Berg (GJM } \\
895,1044,1173 \text { ) }\end{array}$ & huil, mato huil & $\mathrm{N}$ & 32.3 & $\mathrm{Co}(\mathrm{r}), \mathrm{He}(\mathrm{w})$ \\
\hline
\end{tabular}




\begin{tabular}{|c|c|c|c|c|}
\hline \multicolumn{5}{|l|}{ OLEACEAE } \\
\hline Ligustrum lucidum W.T. Aiton (NDJ 2370) & siempre verde & A & 6.5 & $\mathrm{Co}(\mathrm{c}, \mathrm{r})$ \\
\hline \multicolumn{5}{|l|}{ POLYGONACEAE } \\
\hline Ruprechtia apetala Wedd. (GJM 865) & chicharra, chuluca, churrusca & $\mathrm{N}$ & 32.3 & $\mathrm{Co}(\mathrm{o}, \mathrm{r})$ \\
\hline \multicolumn{5}{|l|}{ RHAMNACEAE } \\
\hline Condalia buxifolia Reissek (GJM 881, 940, 1093) & piquillín & $\mathrm{N}$ & 80.6 & $\mathrm{Co}(\mathrm{c}, \mathrm{r}) ; \mathrm{He}(\mathrm{b}) ; \mathrm{St}(\underline{k})$ \\
\hline $\begin{array}{l}\text { Condalia microphylla Cav. (GJM 945, 1090, } 1171 \text {, } \\
\text { 1285; NDJ 2324) }\end{array}$ & piquillín & $\mathrm{N}$ & & \\
\hline Condalia montana A. Cast. (GJM 1182, 1290) & piquillín & $\mathrm{N}$ & & \\
\hline $\begin{array}{l}\text { Sarcomphalus mistol (Griseb.) Hauenschild (GJM } \\
\text { 944) }\end{array}$ & mistol & $\mathrm{N}$ & 19.4 & $\mathrm{Co}(\mathrm{r}) ; \mathrm{St}(\mathrm{k})$ \\
\hline \multicolumn{5}{|l|}{ ROSACEAE } \\
\hline Prunus persica (L.) Batsch (NDJ 2375) & durazno & A & 12.9 & $\mathrm{Co}(\mathrm{c})$. \\
\hline \multicolumn{5}{|l|}{ RUTACEAE } \\
\hline Citrus aurantium L. $\left({ }^{*}\right)$ & naranjo & A & 3.2 & $\mathrm{Co}(\mathrm{c})$. \\
\hline Citrus reticulata Blanco $\left({ }^{*}\right)$ & mandarino & A & 3.2 & $\mathrm{Co}(\mathrm{c})$. \\
\hline $\begin{array}{l}\text { Zanthoxylum coco Gillies ex Hook. f. \& Arn. (GJM } \\
\text { 902,1266; NDJ 1984) }\end{array}$ & $\operatorname{coco}$ & $\mathrm{N}$ & 51.6 & $\mathrm{Co}(\mathrm{c}, \mathrm{o}) ; \mathrm{He}(\mathrm{w}) ; \mathrm{St}(\mathrm{k})$ \\
\hline \multicolumn{5}{|l|}{ SALICACEAE } \\
\hline Populus alba L. (NDJ 2250) & alamo, alamo plateado & A & 16.1 & $\mathrm{Co}(\mathrm{c}, \mathrm{r})$ \\
\hline Populus deltoides W. Bartram ex Marshall $\left(^{*}\right)$ & alamo & A & & \\
\hline Salix humboldtiana Willd. (GJM 929) & sauce & $\mathrm{N}$ & 54.8 & $\mathrm{Co}(\mathrm{c}, 0)$ \\
\hline Salix cf. alba L. $\left(^{*}\right)$ & mimbre & A & 19.4 & $\mathrm{Co}(\mathrm{c}, \mathrm{o}, \mathrm{r}) ; \mathrm{He}(\mathrm{w})$. \\
\hline Xylosma pubescens Griseb. (GJM 898; NDJ 2013) & alfiler, coronillo & $\mathrm{N}$ & 6.5 & $\operatorname{Co}(r)$ \\
\hline \multicolumn{5}{|l|}{ SAPINDACEAE } \\
\hline $\begin{array}{l}\text { Allophylus edulis (A. St.-Hil., A. Juss. \& Cambess.) } \\
\text { Hieron. ex Niederl. (GJM 899, 956) }\end{array}$ & chal chal & $\mathrm{N}$ & 25.8 & $\mathrm{Co}(\mathrm{c}, \mathrm{O}, \mathrm{r}) ; \mathrm{He}(\mathrm{b})$ \\
\hline \multicolumn{5}{|l|}{ SOLANACEAE } \\
\hline Lycium cestroides Schltdl. (GJM 915, 926; NDJ 2267) & piscoyuyo & $\mathrm{N}$ & 6.5 & $\mathrm{Co}(\mathrm{c})$. \\
\hline Nicotiana glauca Graham (GJM 923) & palan palan & $\mathrm{N}$ & 3.2 & $\mathrm{Co}(\mathrm{c})$ \\
\hline \multicolumn{5}{|l|}{ ULMACEAE } \\
\hline Ulmus spp. $\left({ }^{*}\right)$ & olmo & A & 3.2 & $\mathrm{He}(\mathrm{w})$ \\
\hline
\end{tabular}

mitigating the pressure on the tree cover of the Chaco forest. In this sense some authors suggest that when people use a large number of species, the conservation outcome for the forest is better, compared with intensive use of a few plant species (Levy et al. 2002, Ramos et al. 2008).

\section{Firewood and Applications in Sierra de Ancasti}

The greatest number of species was cited for the use category Food preparation with 42 spp. (80\%), followed by Heating $23 \mathrm{spp}$. $(44 \%$,$) and Kindling and production of fire 16$ spp. (31\%) (Table 2). In all there were 464 mentions of firewood use in which a certain species is associated with a particular use (application). Out of these, 375 were referred to the category Food preparation ( $81 \%$ of the total mentions), followed by Heating 62 $(13 \%)$ and Kindling and production of fire 27 $(6 \%)$.

With proportions similar to those reported by Fernández (2017) for rural populations of another area of the montane Chaco (Chaco Serrano, Córdoba), Food preparation is the main destination for fuel resources (48\%), followed by Heating (25\%). However, it should be noted how important Food preparation is in Sierra de Ancasti, with higher values both in number of species and in mentions of use. This reflects the close link between criollos, firewood and food. In fact, cooking is a daily activity, constant throughout the year, which includes various types of practices and activities described above.

The Roast (asado - preparations of meats) is the practice associated with the 
Table 2. Categories of use and applications with the number of species and mentions of firewood use according to the inhabitants of the Sierra de Ancasti, Catamarca, Argentina.

\begin{tabular}{|c|c|c|c|}
\hline Category & Applications & $\mathrm{N}^{\circ}$ sp. $(\%)$ & Mentions (\%) \\
\hline \multirow{4}{*}{ Food preparation } & Cooking and boiling & 27 & 73 \\
\hline & Oven & 15 & 64 \\
\hline & Roast & 28 & 238 \\
\hline & Total & $42(81)$ & $375(81)$ \\
\hline \multirow{4}{*}{ Heating } & Brazier & 13 & 31 \\
\hline & Salamander stove & 2 & 4 \\
\hline & Water heaters & 13 & 27 \\
\hline & Total & $23(44)$ & $62(13)$ \\
\hline \multirow{4}{*}{$\begin{array}{c}\text { Kindling and } \\
\text { production of flame }\end{array}$} & Embers and coals & 7 & 13 \\
\hline & Kindling fire & 11 & 14 \\
\hline & Total & $16(31)$ & $27(6)$ \\
\hline & TOTAL & $52(100 \%)$ & $464(100 \%)$ \\
\hline
\end{tabular}

greatest richness of species (28 spp.). The firewood most mentioned for this purpose were Condalia spp. $(80.6 \%$ of the total interviewees), followed by Vachellia caven (77.4\%) and Lithraea molleoides (61.2\%). Additionally, 12 species used to heat the clay oven traditionally used in rural areas of Argentina were mentioned. The most common species were Zanthoxylum coco $(48.4 \%)$ and Salix humboldtiana (45.2\%). Firewood for the oven is usually considered among the criollos as "weak" (lower caloric power), which makes it ideal for making homemade bread (baked mixture of flour, fat, water and salt).

Three applications were mentioned by the residents in the Heating category (Table 1). Two are directly related to the heating of rooms: Braziers (metal containers which are generally round, wide and deep, and where embers are burned) and Salamander stoves (cast iron stoves equipped with a chimney). Due to its ease of use, reduced firewood consumption, practicality, and small home rooms or spaces, the Braziers are the preferred appliances for heating. In addition, these are used all year round because they heat up and keep water warm to drink mate. A third application in the heating category is Water heaters (old devices for heating water) which nowadays seem to be losing importance in the face of other electrical alternatives (state-of-the-art water heaters, hot water tanks and showers). Furthermore, it should be noted that many times the inhabitants prefer to put a pot of water directly on the charcoals of the stove to heat water for bathing.

Additionally, eleven (11) species were registered as Kindling (young branches, dry stems, pieces of wood), with Sarcomphalus mistol as the most mentioned plant for this application. Seven (7) other species of trees were recognized for their qualitative attributes for use as Embers and charcoals: Celtis spp., Prosopis alba, and Schinopsis lorentzii as the most prominent.

When species were ranked according to the number of use categories "Tala" (Celtis spp.) was the only firewood species mentioned in all categories, so it can be considered the most versatile species 
(Figure 3). Other species considered by inhabitants as having the greatest diversity of applications are Vachellia caven (6), Parasenegalia visco and Lithraea molleoides (5).

Additionally, three practices associated with fire were found, involving five plant species that are not used as firewood and therefore were not included in the treatment of the data. They are plants used as brooms or brushes to clean the ash from the ovens (Baccharis flabellata, Croton lachnostachyus and $C$. lanatus). Residents also indicated that the resin of Cercidium praecox, a tree known in the area as "brea", was previously used to brighten-shine coal. Finally, the ashes of "chuluca" (Ruprechtia apetala) were used for the elaboration of bleach or soap with which clothes were washed.

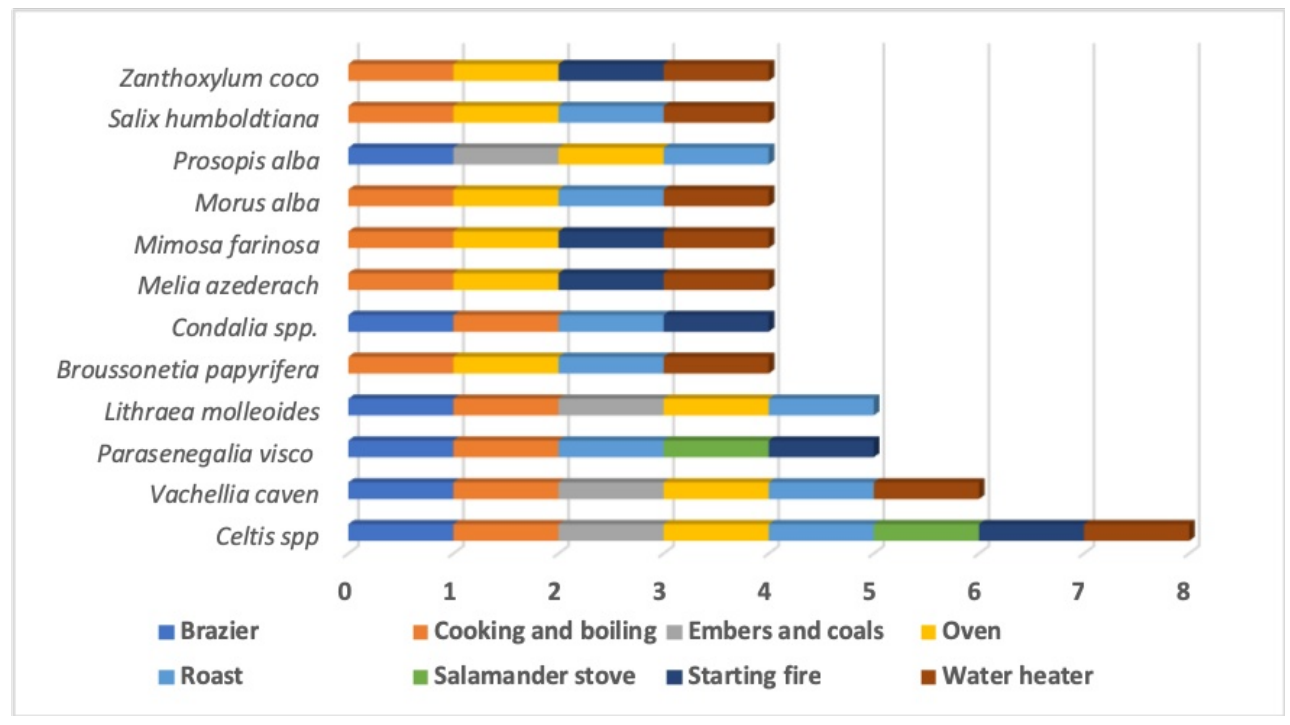

Figure 3. Firewood species with the highest number of applications in the management and production of fire in Sierra de Ancasti, Catamarca, Argentina.

\section{Cultural relevance and last firewood used}

The species of firewood with higher Frequency of mention (Fr) among the inhabitants were: "churqui" (Vachellia caven) and "piquillín" (Condalia spp.), which were cited by more than $80 \%$ of the interviewees (Table 3). Other firewood species such as "tala" (Celtis spp.), "molle" (Lithraea molleoides), "algarrobo" (Prosopis alba) and "quebracho colorado" (Schinopsis lorentzii) also had high frequencies (more than $50 \%$ ). Among the species with greater $\mathrm{Fr}$, only "mora" (Morus alba) is adventitious. Despite being a tree that is not considered "good firewood", it is common to see it in domestic spaces such as patios and gardens.

According to the Cognitive Salience Index (CSI), eleven species are considered by local people as the most important firewood in the area, "Piquillín" (Condalia spp.) and "churqui" (Vachellia caven) being those with the highest position in the CSI (Table 3). Regarding the biogeographic origin, $100 \%$ of the CSI species are native and characteristic of the forest environments of the montane Chaco. The fact that all the important species are native is a reflection of the vast knowledge of the local flora. This may 
Table 3. Positioning of the most important firewood species according to the relative Frequency of mention (Fr) and the Cognitive Salience Index (CSI) in Sierra de Ancasti, Catamarca, Argentina.

\begin{tabular}{lclc}
\hline Species & Fr (\%) & Species & CSI (\%) \\
\hline Condalia spp. & 80.6 & Condalia spp. & 0.30 \\
Vachellia caven & 80.6 & Vachellia caven & 0.28 \\
Celtis iguanaea & 64.5 & Lithraea molleoides & 0.12 \\
Lithraea molleoides & 64.5 & Schinopsis lorentzii & 0.10 \\
Prosopis alba & 58.1 & Celtis spp. & 0.06 \\
Schinopsis lorentzii & 58.1 & Prosopis spp. & 0.05 \\
Parasenegalia visco & 54.8 & Parasenegalia visco & 0.03 \\
Salix humboldtiana & 54.8 & Parapiptadenia excelsa & 0.02 \\
Zanthoxylum coco & 51.6 & Anadenanthera colubrina & 0.02 \\
Anadenanthera colubrina & 48.4 & Zanthoxylum coco & 0.02 \\
Morus alba & 48.4 & Mimosa farinosa & 0.01 \\
\hline
\end{tabular}

indicate that preference is culturally determined, and is a cognitive process that is transmitted and enriched across generations, as Cardoso et al. (2015) describe.

Although cultural relevance can be analysed in terms of consensus among inhabitants (Fr), in the question designed for the CSI the universe of all firewood is reduced to three that represent the most important ones. The species with the highest index scores, calculated according to the frequency and ranking of the answers, are those that are most preferred by the residents.

For Ancasti's settlers, the top ranked species according to the CSI all produce lasting embers. Ember is produced at the moment in which wood or coal stays red and incandescent after the fire has stopped burning. A consensus answer among the criollos is that they choose wood with better embers that produce fires of good quality and long-duration, as confirmed by some responses: "Piquillín and Molle firewood species are by far the best; they can glow for up to two days" (A.B. 63 years old) or "piquillín and molle are nice ember... molle and churqui are left at night and are still glowing the next day" (F.C. 82 years old).

In local terms, quality is based on the flame and the embers and thus, good quality firewood is related to words such as "beautiful, burning, durable, firm, nice, resistant and strong". These words are used by the criollos to describe the positive qualities of firewood, and the intrinsic properties of wood related to how easy it is to light, how long it lasts, how ember is produced, and how slowly the fire burns out. This is in line with studies that indicate that the most important attributes in firewood are those that show rapid drying rate, good duration and production of embers, long burning times, high heating power, strong embers, low humidity or weight when dry, easy ignition and combustion, little smoke, among others (Abbot et al. 1997; Ramos 2008; Kituyi et al. 2001; Tabuti et al. 2003).

When asked about the last firewood species that they used, the criollos mentioned 20 species of fuel plants. Among the most named are Salix humboldtiana and Vachellia caven (Table 4). When categorizing the answers given by the inhabitants of when was the last time they 
used firewood, four categories were generated. The response of greatest consensus was: today (61\%), followed by this week $(29 \%)$, this month $(6 \%)$ and this year $(3 \%)$.

Although this index gives an overview of current and recently used firewood species recalled by the residents, we recorded the use of a few additional species through participant observation. These include Vachellia aroma, Aspidosperma quebrachoblanco, Broussonetia papyrifera, Melia azedarach, Prosopis alba, Sarcomphalus mistol, Schinus fasciculatus and Ulmus spp.

The results of the Re-Call method confirm the wide diversity of firewood in the area and provide insights into the current management of firewood in the Sierra. Although $75 \%$ of the species are native, the other $25 \%$ corresponds to 14 species of adventitious trees (introduced and/or cultivated) that, despite not being included as relevant species in $\mathrm{Fr}$ and CSI, they are firewoods currently used in households. Although considerable knowledge of the local flora (linked to firewood) has already been demonstrated, this group of adventitious species (which are not yet considered by the inhabitants among the most relevant) could be involved in processes of knowledge transformation, where little by little new firewood species are incorporated to meet people's needs, a process that has been suggested for other

Table 4. Recollection of firewood(s) used in the rural community of the Sierra de Ancasti, Catamarca, Argentina.

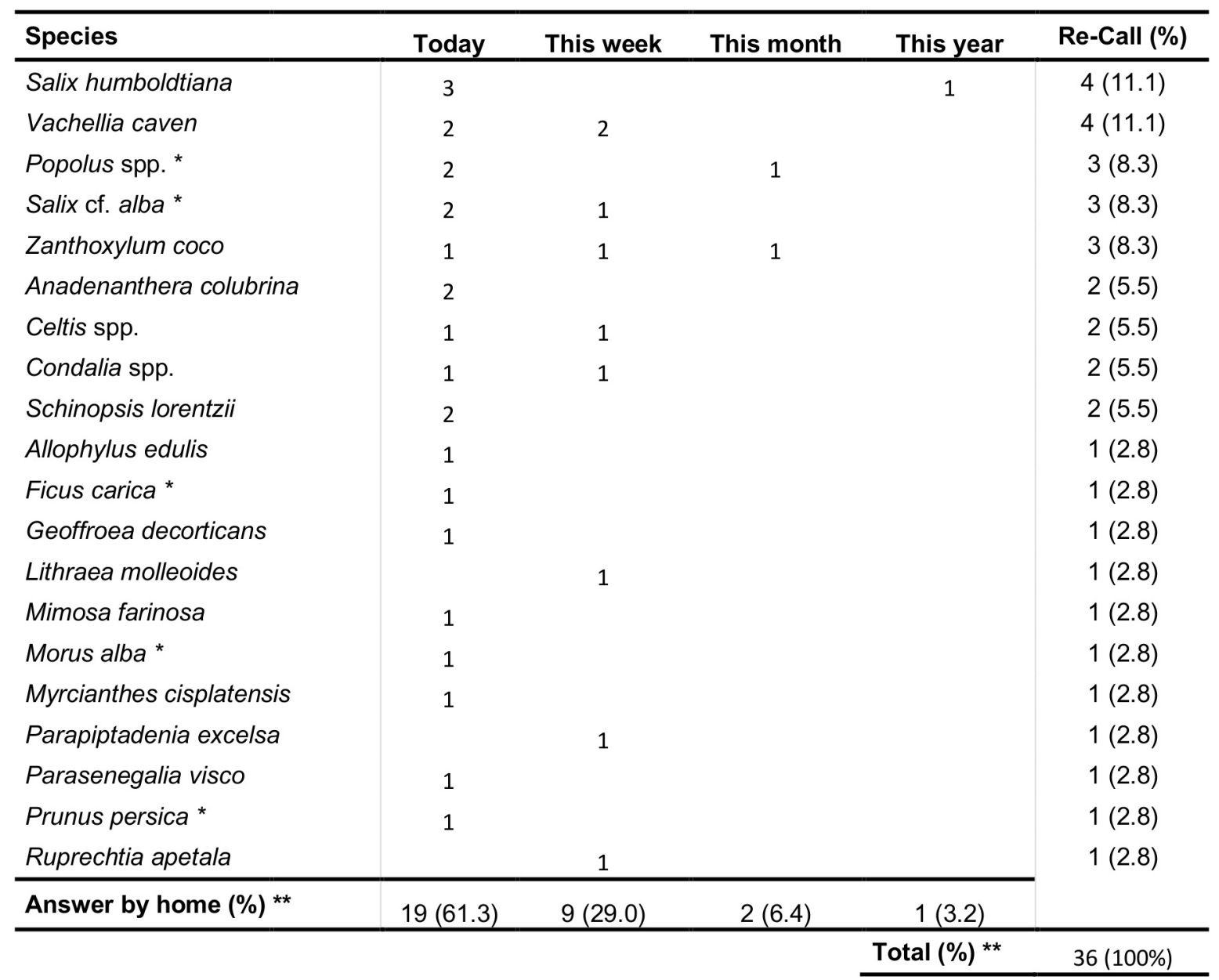

* Adventitious species

** Sometimes the response included more than one species 
rural communities (Cardoso et al. 2015, 2017; Silva et al. 2018). Several authors suggest that adventitious species, due to their easy access, greater availability, rapid growth and greater tolerance than native species, can meet some of the basic needs of the inhabitants and, in a certain way, diversify the supply of plants. The use of these exotic, introduced or cultivated species would also be a way of reducing pressure on native species and, in the case of Ancasti, a measure that could mitigate the clearance and deforestation of the Dry Chaco's ecosystems.

According to Ramos et al. (2008), for the Brazilian Caatinga, there is a correlation between firewood species preferred by residents and the use and selection of species, even claiming that the species most commonly known are those most frequently collected, regardless of availability. However, this pattern seems not to be met for the Sierra de Ancasti. Indeed, adventitious species such as Broussonetia papyrifera, Ficus carica, Melia azedarach, Morus alba, Popolus spp. Prunus persica and Ulmus spp. gain prominence probably because they are associated with domestic spaces (fences, gardens, courtyards), decreasing distances and increasing accessibility, thus making collection easier. As suggested by other studies such as Albuquerque et al. (2009), Cardoso et al. (2012, 2015) and Silva et al. (2018), the frequent use of adventitious species in Sierra de Ancasti could be related to the accessibility of fuelwood.

Regarding cultural appropriation, Marconetto (2008) states that the supply of firewood in human groups is governed by needs and preferences, considering that selection may be determined by cultural principles and not always by the "principle of least effort". Cardoso et al. (2015) considers that the selection of woody species is related to their combustion characteristics under a social foundation resulting from cognitive knowledge (transmitted and enriched through generations). In the particular case of Ancasti, results show that the preferred or relevant species are apparently selected for what they call "quality" (general term, which is associated with the intrinsic properties of wood, such as durability of embers or the heating power of the flame), implied in phrases such as: "Here there is no wood that is not taken advantage of", "Tree that falls or dries, tree that is used for firewood" (H.F. 80 years old) or "everything is wood here" (D.P. 64 years old). According to residents, other factors such as those related to the abundance of the species and the distance required to collect them are central when selecting and using firewood.

Although this study did not evaluate firewood collection patterns according to seasonality, this factor has been shown to have significant negative environmental impacts (Chettri et al. 2002; Ramos and Albuquerque 2012). In Ancasti, the collection of firewood for domestic use may have a negligible direct impact on the native flora as compared with the collection of firewood for commercial use and coal-making in smallscale industries which require large quantities of wood that is sometimes cut green (Tabuti et al. 2003; Win et al. 2018).

\section{CONCLUSIONS}

The inhabitants of the Sierra de Ancasti know, manage, use and appropriate arboreal and shrubby resources to meet their basic domestic needs, such as the preparation of food, and the heating of their homes. Likewise, firewood is important in community and family life, because the practices associated with fire - drinking mate from the 
brazier, or heating rooms during the winter -strengthen the social fabric, and maintain a constant flow of knowledge (environmental, cultural, family and social).

At the local level, the main attributes of Sierra de Ancasti's firewood species are known among the population. However, according to the criollos the selection of species is determined, not only by their quality (intrinsic properties), but also by their availability in terms of accessibility and walking distance. Future studies of these factors will be important to understand the current and actual use of wood energy resources.

It is well known that the intensive use of fuelwood resources can pose a threat to natural ecosystems. However, in the Sierra de Ancasti, several mitigating factors should be considered such as: the high richness of firewood species used and known in the region, the flexibility of the inhabitants in the selection and collection of different species, the exclusive use of firewood for domestic purposes, the collection of dead wood and the use of several adventitious-cultivated species associated with domestic spaces. These factors could be reducing the pressure on the native species and on the Chaco's forests in general.

At present, the effect of the collection of firewood on the species, and its impact on the ecology of populations in Sierra de Ancasti is unknown, and this is a topic that could be of interest future studies. The documentation obtained on fuelwood species represents an important step towards the preservation of knowledge and local environments in the Dry Chaco. Furthermore, understanding peoples' perceptions and the different forms of resource appropriation can strengthen conservation strategies in the Chaco forest by integrating local values and practices, guided by principles of respect and inclusion.

\section{ACKNOWLEDGEMENTS}

We would like to thank the Institute of Anthropology of Córdoba (IDACOR) and the Museum of Anthropology of the National University of Córdoba. We are also grateful to the Herbarium of the Botanical Museum (CORD) and the Secretary of State for the Environment and Sustainable Development of the Province of Catamarca. Thanks to Lauren Raz and Carolina Mosconi for revising and translating the manuscript. To Ana Piovano and Fernando Zamudio for the critical reading and the valuable comments. We are particularly thankful to the criollosserranos of the region who, with extraordinary generosity, have informed us of the firewood of the area. We would also like to thank the National Council for Scientific and Technological Research (CONICET) and ANPCyT/FONCyT project, Pict 1001 and 1633, for financial support.

\section{REFERENCES}

Abbot P, Lowore J, Khofi C, Werren M (1997) Defining firewood quality: A comparison of quantitative and rapid appraisal techniques to evaluate firewood species from southern African Savanna. Biomass and Bioenergy 12(6): 429-437

Alexiades MN (1996) Standard Techniques for Collecting and Preparing Herbarium Species. In: Alexiades M.N. (eds.) Selected guidelines for ethnobotanical research: A field manual. New York Botanical Garden. Bronx, New York, USA

Albuquerque UP, Lucena RFP, Alencar NL (2014). Methods and techniques used to collect ethnobiological data. In: Albuquerque UP, Lucena RFP, Cunha LVF (eds) Methods and techniques in ethnobiology and ethnoecology, 1st edn, Springer, New York, pp 15-37

Anderson EN, Pearsall DM, Hunn ES, Turner NJ (2011) Ethnobiology. Wiley Blackwell, USA.

Arre J, Molares S, Ladio A, Kustschker A (2015) Etnobotánica de plantas leñateras y su circuito comercial en una ciudad de la Patagonia Argentina. Gaia Scientia 9(3): 41-48 
Bazán AR (2006) Los pueblos de Ancasti. Editorial Sarquís, Catamarca, Argentina

Cardoso B, Ladio AH (2011) Forestación peridoméstica en Patagonia y conocimiento ecológico tradicional: un estudio de caso. Sitient. Ciênc. Biol. 11: 321-327

Cardoso B, Ladio AH, Lozada M (2012) The use of firewood in a Mapuche community in a semi-arid region of Patagonia, Argentina. Biomass and Bioenergy 46:155-164

Cardoso B, Ladio AH, Lozada M (2013) Fuelwood consumption patterns and resilience in two rural communities of the northwest Patagonian steppe, Argentina. Journal of Arid Environments 98: 146-152

Cardoso B, Ladio AH, Dutrus S, Lozada M (2015) Preference and calorific value of fuelwood species in rural populations in northwestern Patagonia. Biomass Bioenergy 81: $514-520$

Cardoso B, Ladio AH (2017) Niche breadth and redundancy: Useful indices to analyse fuelwood use in rural communities. Journal of Arid Environments 145: 52-59

Chettri N, Sharma E, Deb DC, Sundriyal RC (2002) Impact of firewood extraction on tree structure, regeneration and woody biomass productivity in a Trekking Corridor of Sikkim Himalaya. Mountain. Research and Development 22 (2): 150-158

Chettri N, Sharma E (2009) A scientific assessment of traditional knowledge on firewood and fodder values in Sikkim Himalaya. Forest Ecology and Management 257(10): 2073-2078

Eyssartier C, Ladio AH, Lozada M (2009). Uso de plantas medicinales cultivadas en una comunidad semi-rural de la estepa patagónica. Blacpma 8: 77-85

FAO - Organización de las Naciones Unidas para la Agricultura y la Alimentación (1983) Wood fuel survey - Forestry for local community development programme [http://www.fao.org/docrep/Q1085E/q1085e00.ht m\#Contents] Accesed 05 February 2018

FAO - Organización de las Naciones Unidas para la Agricultura y la Alimentación (2008) Bosques y energía: cuestiones clave [http://www.fao.org/3/a-i0139s.pdf ] Accesed 15 February 2018
Fernández AE (2017) Conocimiento, provisión y uso de plantas alimenticias y combustibles en pobladores rurales de los ambientes serranos de La Calera (Depto. Colón, Córdoba). Undergraduate thesis, Universidad Nacional de Córdoba, Argentina

Fox J (1984) Firewood consumption in a Nepali village. Journal of Environmental Management 8 (3): 243-250

Gadban L (1999) Materiales vegetales leñosos utilizados como maderas y combustibles en el Valle del Ambato (Provincia de Catamarca). Undergraduate thesis, Universidad Nacional de Córdoba, Argentina

Ghilardi A, Guerrero G, Masera O (2007) Spatial analysis of residential fuelwood supply and demand patterns in Mexico using the WISDOM approach. Biomass Bioenergy 31(7): 475-491

Guber R (2004) El salvaje metropolitano, Reconstrucción del conocimiento social en el trabajo de campo. Editorial Paidos, Buenos Aires, Argentina

Höft M, Barik SK, Lykke AM (1999) Quantitative Ethnobotany. Applications of multivariate and statistical analyses in ethnobotany. People and Plants Working Paper (6): 1-46

INDEC - Instituto Nacional de Estadística y Censos. República de Argentina (2010) [http://www.indec.gov.ar/] Accesed 15 April 2017

ISE - International Society of Ethnobiology (2006) Code of Ethics. [http://ethnobiology.net/code-of-ethics/] Accesed 22 January 2018

Jiménez-Escobar ND (2015) Entre azahares y chaguares: las bromelias forrajeras de las Sierras de Ancasti, Catamarca, Argentina. Gaia Scientia 9(3): 1-6

Karremans J (1994) Sociología para el desarrollo, métodos de investigación y técnicas de la entrevista. Serie técnica, informe técnico $\mathrm{N}^{\circ}$ 228. Centro Agronómico Tropical de Investigación y Enseñanza (CATIE). Turrialba, Costa Rica

Kataki R, Konwer D (2002) Fuelwood characteristics of indigenous tree species of north-east India. Biomass and Bioenergy 22: $433-437$ 
Kituyi E, Marufu L, Wandiga S, Jumba IO, Andreae M, Helas G (2001) Biofuel availability and domestic use patterns in Kenya. Biomass and Bioenergy 20: 71-82

Levy SI,Aguirre JR, Martínez MM, Durán A (2002) Caracterización del uso tradicional de la flora espontanea en la comunidad Lacandona da Lacanhá, Chiapas, México. Interciencia 27(10): 512-20

Luján MC, Martínez GJ (2017) Dinámica del conocimiento etnobotánico en poblaciones urbanas y rurales de Córdoba (Argentina). BLACPMA 16 (3): 278-302

Maldonado VP (2011) Plan estratégico territorial de la Provincia de Catamarca: Informe de Avance II: año 2011. Gobierno de Catamarca, Catamarca, Argentina

Marconetto MB (2008) Recursos forestales y el proceso de diferenciación social en tiempos prehispánicos en el Valle del Ambato, Catamarca, Argentina. Izeta AD (ed.) BAR International Series 1785. Oxford, UK, pp. 199

Martin G (2001) Etnobotánica. Manual de Conservación. Serie "Pueblos y Plantas". WWFUK. UNESCO y Royal Botanic Gardens, Kew, UK. Ed. Nordan Comunidad. Montevideo, Uruguay, pp. 240

Martínez GJ (2015) Cultural patterns of firewood use as a tool for conservation: A study of multiple perceptions in a semiarid region of Cordoba, Central Argentina. Journal of Arid Environments 121: 84-99.

Martínez GJ, Jiménez-Escobar ND (2017) Plantas de interés veterinario en la cultura campesina de la Sierra de Ancasti (Catamarca, Argentina). BLACPMA 16 (4): 329 - 346

Morales DV, Molares S, Ladio AH (2017) Firewood resource management in different landscape in NW Patagonia. Front. Ecol. Evol. 5: 111

Mori SA, Berkov A, Gracie CA, Hecklau EF (2011) Tropical Plant Collecting. From the Field to the Internet. TECC Editora, Florianópolis, Brazil, pp. 332

Morláns MC (1995) Regiones Naturales de Catamarca, Provincias Geológicas y Provincias Fitogeográficas. Revista de Ciencia y Técnica 2 (2):1-42
Palmeri CN, Carma IM, Quiroga A (2008) La Ecorregiones de Catamarca. Atlas de Catamarca. Universidad Nacional de Catamarca, Facultad de Ciencias Agrarias. [http://www.atlas.catamarca.gov.ar] Accesed 01 September 2017

Perea MV, Pedraza G, Luceros J (2007) Relevamiento de la flora arbórea autóctona de la provincia de Catamarca. Consejo Federal de Inversiones, Buenos Aires, Argentina

Perea MV (2011) Relevamiento de Cactáceas en la provincia de Catamarca. Consejo Federal de Inversiones, Buenos Aires, Argentina

Quiroga A, Reinoso-Franchino G (2010) Árboles nativos de la provincia de Catamarca. Atlas Catamarca. Gobierno de la Provincia de Catamarca, Facultad de Ciencias Agrarias. [http://www.atlas.catamarca.gov.ar] Accessed 01 September 2017

Quiroga A, Correa RJ (2011) Gramíneas forrajeras presentes en el Chaco Árido de Catamarca. Revista de Divulgación Técnica Agrícola y Agroindustrial (16):1-12

Ramos MA, Medeiros PM, Almeida ALS, Feliciano, Albuquerque UP (2008) Use and knowledge of fuelwood in an area of Caatinga vegetation in NE Brazil. Biomass Bioenergy 32: 510-517

Ramos MA, Albuquerque UP (2012) The domestic use of firewood in the rural communities of the Caatinga: How seasonality interferes with patterns of firewood collection. Biomass and Bioenergy 39: 147-158

Rodriguez S, Arias-Toledo B, Galetto L (2015) Use of wood resources in Central Argentina: A multivariate approach for the study of phytogeography and culture. Ethnobotany Research \& Applications 14: 381-392

San V, Spoann V, Ly D, Chheng NV (2012) Fuel consumption patterns in Chumriey Mountain, Kampong Chhnang Province, Cambodia. Energy 44: 335-346

Silva APT, Medeiros PM, Ferreira WS, Silva RRV (2018) Does forest scarcity affect the collection and use of firewood by rural communities? A case study in the Atlantic Forest of Northeastern Brazil. Economic Botany 72: 1-10

Sutrop U (2001) List task and a cognitive salience index. Field Methods 13(3):263-276

Tabuti JRS, Dhillion SS, Lye KA (2003). 
Firewood use in Bulamogi County, Uganda: species selection, harvesting and consumption patterns. Biomass and Bioenergy 25: $581-596$

Valderrama E, Linares EL (2008) Uso y manejo de leña por la comunidad campesina de San José de Suaita (Suaita, Santander, Colombia). Revista Colombia Forestal 11: 19-34
Win ZC, Mizoue N, Ota T, Kajisa T, Yoshida S, Naing T, Ma H (2018) Differences in consumption rates and patterns between firewood and charcoal: A case study in a rural area of Yedashe Township, Myanmar. Biomass and Bioenergy 109: 39-46
Received: 20 October 2018

Accepted: 21 November 2018

Published: 29 November 2018 